\title{
THE TRAGEDY OF THE ÑÁNIGOS: GENESIS OF AN UNPUBLISHED BOOK
}

Although the Cuban anthropologist Fernando Ortiz was born in Havana in 1881 , during the first fifteen years of his life, he lived and went to school in the town of Ciutadella de Menorca, in the Balearic Islands. ${ }^{1}$ He hailed from a cultured family that had grown prosperous from its business ventures, including the establishment of the shoe industry on the island. His childhood home was one receptive to the new scientific ideas that were making their way across Spain and, little by little, across the old Menorcan island. Ortiz thus received an education in line with the ideas of German Krausism, a school of thought, influential in Spain at the time, that proposed a pedagogy in accord with the modernity of the scientific revolution and the technological advances of the second half of the nineteenth century. ${ }^{2}$ Joan Benejam, Ortiz's teacher in primary school, was an outstanding pedagogue, a supporter of Krausism, and a proponent of innovative educational methods, from which Ortiz undoubtedly benefited (Ortiz 1906a).

Between 1898 and 1902, while Ortiz was earning his bachelor's degree and a doctorate in law in Spain, he was introduced to the main currents of progressive thought of the time, and he immersed himself in the study of new disciplines, such as sociology and criminology, that complemented his training as a lawyer. He took a vivid interest in the theories of Cesare Lombroso and the Italian criminological school regarding the phenomenon of the mala vida, and he decided to investigate, upon his return to Cuba, the "margins" of Havana society where beggars, prostitutes, "wizards," thieves, and criminals swarmed. ${ }^{3}$ This he intended to undertake in collaboration with two friends

1. This article has been translated by Elizabeth Pérez and Stephan Palmié.

2. From Karl Christian Friedrich Krause (1781-1831), whose Romantic thought profoundly shaped Spanish liberalism.

3. In Spanish, la mala vida connotes not only a life badly lived - the literal translation - but an entire "urban underworld": a class of subalterns that the state in the early twentieth century increasingly sought to control. The immediate inspiration for the project clearly was de Quiros and Llanas Aguilaniedo (1901). See p. 231.

New West Indian Guide / Nieuwe West-Indische Gids vol. 79 no. 3 \& 4 (2005):229-237 
and fellow-professionals: the physician Miguel de Carrión and the journalist Mario Muñoz Bustamante, who together with Ortiz in his capacity as a criminal lawyer, were called upon to add their respective professional abilities and experiences to the project. Although that project could not be completed in its entirety, three publications resulting from it can be counted as lasting contributions to Cuban intellectual culture: Fernando Ortiz's book Los negros brujos (1906b), and two novels in the psychological-social style, Las honradas (1917) and Las impuras (1919) by Miguel de Carrión, whose application of medical thought to the creation of the so-called "Cuban naturalist novel" makes him one of the most important Cuban novelists of the first half of the twentieth century.

From his positivist beginnings, which evolved with time into a conscious historicism, Fernando Ortiz studied and investigated Cuban national identity in its historical, cultural, economic, and social aspects. On the foundation of previous knowledge, he rediscovered, re-elaborated, and applied concepts that brought about new scientific results, like transculturation, mulatez and lo afrocubano. ${ }^{4}$ In this, his work as a researcher was complemented by his

4. Transculturation is a term coined by Ortiz; mulatez, a term promoted by Ortiz; and lo afrocubano, one that was rehabilitated by Ortiz. Raised in the Old World yet committed to the essential newness of Cuban forms of sociality and culture, Ortiz believed that their description required the judicious use of neologisms. Transculturation was an attempt to amend the North American concept of acculturation, and to transcend its mechanistic and ultimately Eurocentric implications of unidirectional change in cultural contact situations. Instead, Ortiz sought to reveal the intricate processes of mutual influence and fusion from which emerged essentially novel cultural syntheses that subsume their antecedents, but cannot be understood as mere additive "mixtures" of heterogeneous elements. Similarly, in an unfinished manuscript entitled La epifanía de la mulatez (Instituto de Literatura y Lingüística José Antonio Portuondo, Havana, Fernando Ortiz Collection, folders 274-75), Ortiz insists that racial mixture provides an inadequate analogy to the cultual productions that emerged from the contact of Europeans and Africans in the Americas: "It is said that mulatez is the [result] of the ethnic mixture of whites and blacks." But, so he asks, "what can we understand, ethnographically, as white, and what as black?" For these are categories and identities that are themselves the product of complicated historical processes, rather than "natural" (or otherwise "given") kinds. Instead, Ortiz argues that mulatez or lo mulato ought to designate an equally novel form of being and acting - a condition that is sui generis, entirely "of the New World," and irreducible to its Old World antecedents. The same holds true for lo afrocubano a term Ortiz claimed had been used before by Antonio de Veitía in 1847, but which he re-introduced to "express with exactitude the originary duality of the social phenomena with which I was concerned" (Ortiz 1943). Different from, for example, the black North American sociologist W.E.B. DuBois (1997:38), for whom the painful irreconcilability of "blackness" and "Americanness" in the United States at the beginning of the twentieth century appeared to result in a paradoxical sense of "double consciousness," by the 1930s, for Ortiz, lo afrocubano had come to designate an organic form of social being inseparable from the Cuban national project he was advocating. 
activities as the promoter and founder of institutions, societies, and publications of a scientific, cultural, and patriotic character. To an extent rivaled by few contemporary intellectuals, he, along with his young disciples engaged in, and actively shaped, the political and social events in Cuba occurring mainly during the decades between 1920 and 1950.5

Although the original plan to investigate la mala vida and el hampa afrocubana (the Afro-Cuban underworld, was never to be realized in its entirety, Fernando Ortiz would, over the course of decades, accumulate ample information that he molded into prospective books, which he kept "fortifying" for years and years, and occasionally was to leave unfinished. Such was to be the case with "Los negros horros," "Los negros ñáñigos" and "Los negros curros," the latter of which was published posthumously in 1986, thanks to the Cuban researcher Diana Iznaga, who followed Ortiz's original notes and plan for the manuscript in establishing the final text. But it is important to note here that the idea of writing a study of los ñánigos 6 - as Ortiz himself repeatedly acknowledged - did not just remain a continuing concern for him, but had actually stood at the very beginning of his lifelong explorations of matters Afro-Cuban. As he recalled in 1939, when he received his doctorate in Madrid in 1901, he was asked to comment on the monograph La mala vida en Madrid: Estudio psicosociológico (1901) by the Spanish criminologists Constancio Bernaldo de Quirós and José María Llanes Aguilaniedo, and to specify in what way Havana's urban underworld differed from that of Cuba's former metropole. "I felt considerable pressure because I knew very little about this difficult subject," he wrote with forty years of hindsight,

\begin{abstract}
but I came away with flying colors, talking about something as exotic as the ñánigos, of whom I then knew nothing else than what Trujillo y Monagas had published in his work Los criminales de Cuba, and what I had seen in Madrid's Museo de Ultramar where there are some costumes of diablitos, [musical instruments], and other accessories of this association which had enjoyed such theatrical fame during the colonial period. But in reality, I knew nothing of the ñáñigos, and from then onward I set myself the task of studying them. (Ortiz 1939:86)
\end{abstract}

It was to become a lifelong pursuit. When, in 1917, Ortiz published the second, revised edition of Los negros brujos, he wrote in the preface

The fervor of him who dedicates himself to the study of the Afro-Cuban underworld ("Hampa Afro-Cubana") has not abated. I have just finished a book: Los

5. Among these counted the historian Julio le Riverend Brusone (1911-98), the musicologist Argeliers León (1918-91), the literary scholar and critic José Antonio Portuondo Valdor (1912-96), and the writers and revolutionary leaders Pablo de la Torriente Brau (1901-36), Rubén Martínez Villena (1899-1934), and Juan Marinello Vidaurreta (1898-1977).

6. That is, the secret male society Abakuá (See Palmié \& Perez, pp. 219-27 of this issue). 
Negros Esclavos, ${ }^{7}$ and within a short time I will conclude another: Los Negros Horros, ${ }^{8}$ and beyond these, three more will have to be completed: Los Negros Curros, ${ }^{9}$ Los Negros Brujos, ${ }^{10}$ and Los Negros Náánigos. (Ortiz 1917:7)

In the same year, he wrote his résumé11 in applying for a professorial chair in criminal law at the Universidad de La Habana. There he proposed that his collection of works "on the Hampa Afrocubana will be reconsolidated ... as a necessary introduction to a full anthropo-sociological understanding of black criminality in Cuba" and added that the results of this "will include ... a book ... about Los Negros Ñáñigos [currently] in preparation (1000 pages)."

In a letter written to the Cuban essayist José María Chacón y Calvo in 1927, Ortiz assured him

\begin{abstract}
Rafael Salillas, the eminent Spanish anthropologist and criminalist, published - it must have been some 30 years [ago] — an article about los ñáñigos in a Spanish journal. By letter he told me that this work was a study, already completed, though unedited, that he planned to publish. He didn't. And that study remained unpublished. I am going to work this year on finishing a very extensive book, Los Ñánigos, and it occurs to me that you, such a fortunate forager among old documents, might procure, among the papers that that old sage left when he died, some unedited sheets of paper or drawings, etc. Might we be so lucky? If we manage to ascertain the whereabouts of his relatives, it might be easy; or maybe the old prison employees, or [Salilla's] editors (V. Suárez, among others), could give you information. I am interested in mastering this subject in order to be able to cover the theme of nañiguismo as fully as possible. It is something really original, which must be of interest to anthropologists and sociologists." 12
\end{abstract}

And yet, the book on what Ortiz (1943) called "the most characteristic of the colored element in Cuba, that is the mystery of the secret societies of African origin which still survive in our land" - a subject that had fascinated him since his student days in Madrid - remained a work in progress. Reminiscing about the beginnings of his career as an investigator of Afro-Cuban culture in front of a largely black audience at the Club Atenas in 1942, he recalled how at the beginning of the twentieth century

7. Published in 1916.

8. "The Free Blacks" - a book project that apparently never reached the stage where Ortiz began to gather materials in clearly marked files (see Díaz 1998)

9. Posthumously edited from a series of articles Ortiz published in Archivos del folklore cubano (Ortiz 1926-28), and his files by Diana Iznaga (Ortiz 1986).

10. Apparently he was planning a new edition even at the time he had just published a revised version of the first!

11. Biblioteca Nacional José Martí, Havana, Fernando Ortiz Collection.

12. Letter from Ortiz to Chacón, March 10, 1927 (in Gutiérrez Vega 1982:68). 
Everyone talked about [the ñánigos], but no one really knew the truth. It seemed to be a shady business, about which there were many macabre fables and bloody tales, all of which served to spur my own interest. I even offered to a Publisher, a friend of mine, a book I was to write within a year. Forty years have elapsed and the book is not yet written, notwithstanding the wealth of facts and observations I have accumulated. (Ortiz 1943)

Though references to the ñánigos appeared in some works written by el sabio during the 1930s and 1940s, it was not until the 1950s that he would write La africanía de la música folklórica de Cuba (Ortiz 1950a), Los bailes y el teatro de los negros en el folklore de Cuba (Ortiz 1951), and Los instrumentos de la música afrocubana (Ortiz 1952-55), in which he summarized noteworthy aspects of abakuá ceremonies, including their sacred music and dances. ${ }^{13}$ However, the most extended treatments of this theme are to be found in a series of articles relating to the ñannigos that appeared in published form in issues of the magazines Bohemia and Cuadernos Americanos and contain abundant information that was the fruit of his great patience in gathering data over the course of many years.

These articles were "La tragedia de los ñáñigos" (Ortiz 1950b), "Los espíritus o diablitos de los ñáñigos" (Ortiz 1950c), ¿Dónde hay ñáñigos?" (Ortiz 1950d), and "El origen de la tragedia y los ñáñigos" (Ortiz 1950e), ${ }^{14}$ and they unmistakably demonstrate that he had again taken up the theme and was trying then to turn into text the hundreds of files and notes contained in his archives. As on other occasions, Ortiz was obviously in the process of building up and "fortifying" the book on the ñáñigos that he had repeatedly announced as part of his long-term research agenda.

When in 1954 Columbia University, as part of the commemoration of the bicentennial of its founding, decided to award him the title of Doctor Honoris Causa, Ortiz had the chance to return to New York to see old friends and colleagues, as well as to meet prominent anthropologists like Vera Rubin, who was to occupy the position of director of research in Columbia's Department of Anthropology in 1956. In the course of a visit that she made to Ortiz's home in Havana during January of that year, she had the opportunity to gain access to manuscripts concerning the ñáñigos. According to her own words, she came away amazed.

13. Apart from el sabio "the sage," Ortiz acquired a long list of epithets in Cuba, including el pensador "the thinker," and el tercer descubridor de Cuba "the third discoverer of Cuba" (after Columbus and von Humboldt, that is).

14. "The Tragedy of the Náñigos," "The Spirits or the Little Devils of the Náanigos," "Where are [the] Ñánigos?," and "The Origin of Tragedy and the Ñáñigos." 
In a letter to Rubin dated March 23 of the same year, Ortiz says,

\begin{abstract}
Concerning the project of writing and publishing a volume on "The Secret Society of the Black Ñánigos of Cuba," I think that it would be of great interest because that all-male secret society constitutes a social phenomenon, unique in the Americas, of a secret society, of West African origin that has established itself for almost a century and a half in Cuba and maintains its own organization, mythology, language, rites, and some of the social functions deriving from Africa. To write that book I have all the necessary materials, gathered laboriously throughout my fifty years of research about the life of Afro-Cubans. The aforementioned study would comprise the origin of the Society of the Náñigos in Africa and in Cuba, its history, its activities, its organization, its important figures, its rites, its music, its songs, its dances, its spread in Cuba, its current functioning, and its future. ${ }^{15}$ I think that the work of writing [it up] could be done in one year. The translation would not be difficult, since it would not be dealing with a work in a literary style ... Whatever is decided on this subject, it should be as soon as possible, in order for me to allocate my time properly. Now, going on 75 years of age, I do not have any spare time left. ${ }^{16}$
\end{abstract}

Between both researchers there began an interesting exchange of letters discussing the project of publishing the book in an English translation that would improve its circulation within the North American academic field, and more generally within the Anglophone world, the main recipient of research produced on black ethnology and anthropology. ${ }^{17}$ Rubin urged Ortiz to conclude the book, showing him how indispensable the publication of such an important essay would be for the social sciences. But Ortiz explained the difficulties involved for him in undertaking the enormous task of organizing the materials contained in thirty-one folders and editing the definitive text, now at seventy-five years of age and having lost his vision in one eye. In one letter dated October 11 of the same year, she wrote to him on the matter:

You had told me of the vast accumulation of documents which you have been collecting over the years on cultural and historical materials relating to Cuba and Spain, in addition to your data on the Nañigo. You felt at the time

15. It is unclear whether Ortiz is using the word funciones in a functionalist sense to mean "social functions" or whether he means ritual performances.

16. Biblioteca Nacional José Martí, Letter from Fernando Ortiz to Vera Rubin, Havana, March 23, 1956, folder 174, Correspondencia Q-R, Fernando Ortiz Collection. I did a check of the compilation of the letters in order to file/introduce the difficulties he was having with writing, something common with Ortiz at that time due to the problems he had with his eyesight.

17. Unfortunately, I have not found the complete correspondence between them, so that on some occasions one must extrapolate the exact content of the lost letters, although under these circumstances this has not turned out to be an obstacle to tracing the events that are narrated therein. 
that they could devote himself [sic] to classifying and analyzing the data for social science use. I reported this conversation to my colleagues on my return, and since we are concerned with the preservation and publication of scholarly materials pertaining to Caribbean culture, we have been casting about to find a suitable research assistant for this purpose. We believe that we have now located a person who may serve you in this capacity, if you are still interested in making your materials available to the scientific world. ${ }^{18}$

The assistant chosen on the North American side was Dr. Segundo Eleazar Bernal, a Columbian, known in the scholarly world through this relationship with Columbia University, as a Guggenheim Foundation fellow, and it was supposed that, given his situation as a Latin American and a Spanish speaker, this would promote a cordial relationship between both researchers. Ortiz's response, dated November 28, was the following:

\begin{abstract}
The proposal that you have made does me great honor and I am extremely thankful for it ... But for now I do not feel I have the strength to organize [this] work in a manner where I could fully take advantage of Mr. Eleazar's cooperation. I understand that it would please him to work on a study concerning survivals of African religions in Cuba, about which a systematic study with a scientific grounding is needed. If he were to pass through Havana on his return flight to Colombia, it would be a pleasure to speak with him about these matters. ${ }^{19}$
\end{abstract}

In spite of the interest shown by the scientific community of the time in the moment at which Los negros ñánigos or La Sociedad secreta de los negros ñánigos de Cuba would materialize, its publication could not be achieved. Still, Ortiz did finish writing the text, although perhaps without the polish of a stylistic revision and editing. In the "depths" of his personal archives there is an impressive number of folders replete with files and other invaluable documentary collections that represent but one part of the important results of the acumen and investigatory perseverance of Fernando Ortiz. But unfortunately, and in spite of the overwhelming testimony of people close to Ortiz who knew and read the manuscript of the book during his life, along with others who saw it among his papers at a later date, when the work of describing Ortiz's archive began in 1985, his book on the ñánigos was not to be found.

Nowadays diverse works on the ñáñigo theme have been published, even with information collected directly from el sabio himself. Even so, the first such book conceived in the twentieth century now is no longer in the archive

18. Biblioteca Nacional José Martí, folder 174, Correspondencia Q-R, Fernando Ortiz Collection, Letter from Rubin to Ortiz, New York, October 11, 1956.

19. Biblioteca Nacional José Martí, folder 174, Correspondencia Q-R, Fernando Ortiz Collection, Letter from Ortiz to Rubin, Havana, November 28, 1956. 
of Fernando Ortiz. The richness of its contents fully exceeds, perhaps in spite of the most modern judgments, those written later. God willing, one day the book "that is yet to be written" can be published, found once again, in order to render just tribute to him, the one who developed and edited his papers throughout his intellectual life (see Palmié and Pérez, this issue).

\section{APPENDIX}

Folders corresponding to the header "Ñáñigos" in Instituto de Literatura y Lingüística Dr. José Antonio Portuondo, the Fernando Ortiz Collection.

1 Ñáñigos

2 Ñáñigos III - Notas Varias

3 Ñáñigos

4 Ñáñigos

5 Ñáñigos - Legislación

6 Ñáñigos - Barrios Habana

7 Ñáñigos

8 Ñáñigos - Vocablos

9 Ñáñigos - Fotos - Dibujos

10 Ñáñigos - Historia

11 Ñáñigos - Libretas

12 Náñigos - Ritos

13 Ñáñigos - Fotos - Abakuá

14 Náñigos

15 Ñáñigos - Funeral - Lloro

16 Ñáñigos - Írime

17 Náñigos - Funciones
18 Ñáñigos - Psicología - Edad Oficios

19 Ñáñigos - Profilaxis

20 Ñáñigos - Organización

21 Ñáñigos - Sociedades Secretas

22 Ñáñigos - General

23 Ñáñigos - Tatuajes - Sellos Firmas

24 Ñáñigos - Ritos - Ekue

25 Ñáñigos - Varios

26 Ñáñigos - 1930 - 1933

27 Ñáñigos - 1903 - 1939

28 Ñáñigos

29 Ñáñigos - Etnias

30 Ñáñigos

31 Náñigos

\section{REFERENCES}

CARrión, Miguel DE, [1917]. Las honradas. n.p.

—, 1919. Las impuras. n.p.

DíAZ, MARÍA DEL Rosario, 1998. Archivo de Fernando Ortiz: Inventario. In Interamericas Foundation (ed.) Miscelanea II de estudios dedicados a Fernando Ortiz. New York: Interamericas, pp. 215-43.

-, 2003. La iniciación intelectual de Fernando Ortiz. Cuadernos hispanoamericanos 641:43-48.

DuBors, W.E.B., 1997. The Souls of Black Folk. Boston MA: Bedford Books. [Orig. 1906.] 
Gutiérrez Vega, Zenaida, 1982. Fernando Ortiz en sus cartas a José María Chacón (1918-1936, 1956). Madrid: Fundación Universitaria Española.

OrTiz, Fernando, 1906. Joan Benejam. Cuba y América 20(16):243-44.

-, 1906b. Los negros brujos: Apuntes para un estudio de etnologia criminal. Madrid: Editorial América.

—, 1917. Los negros brujos. Madrid: Editorial América.

-, 1926-28. Los negros curros. Archivos del Folklore Cubano 2:3-4; 3:1-4.

—, 1939. Brujos o santeros. Estudios Afrocubanos 3:85-90.

-, 1943. Por la integración cubana de blancos y negros. Ultra 13:77.

-, 1950a. La africanía de la música folklórica de Cuba. Havana: Ministerio de Educación, Dirección de Cultura.

—, 1950b. La "tragedia” de los ñáñigos. Cuadernos Americanos 9(4):79-101.

—, 1950c. Los espíritus o diablitos de los ñáñigos. Bohemia 42(39):20-21, 114-15.

—, 1950d ¿Dónde hay ñáñigos? Bohemia 42(43):4-5, 144-45, 156.

—, 1950e. El origen de la tragedia y los ñáñigos. Bohemia 42(50):26-28, 138-41.

-, 1951. Los bailes y el teatro de los negros en el folklore de Cuba. Havana: Ministerio de Educación, Dirección de Cultura.

-, 1952-55. Los instrumentos de la música afrocubana, vol I-V. Havana: Ministerio de Educación, Dirección de Cultura.

-, 1986. Los negros curros. Havana: Editorial Ciencias Sociales.

Quirós, Constancio Bernaldo \& José María de Llanes Aguilaniedo, 1901. La mala vida en Madrid: Estudio psicosociológico. Madrid: Cerra.

María del Rosario Díaz

Biblioteca Nacional José Martí

Plaza de la Revolución

Havana, Cuba

<proycan@bnjm.cu> 